\title{
ANALISIS PERHITUNGAN HARGA POKOK PRODUKSI PRODUK SPRING BED PADA PT. MASSINDO SINAR PRATAMA
}

\author{
Eric Joseph Taroreh \\ Jantje J. Tinangon \\ Inggriani Elim
}

Fakultas Ekonomi dan Bisnis

Universitas Sam Ratulangi Manado

email: Taroreh.eric89@gmail.com

\begin{abstract}
ABSTRAK
Penentuan harga pokok produksi merupakan masalah penting dalam perusahaan manufaktur dimana kegiatannya adalah mengolah bahan mentah menjadi bahan jadi selanjutnya dijual ke konsumen untuk memperoleh laba.Harga pokok produksi adalah biaya produksi yang diterapkan oleh seluruh produk jadi yang telah selesai diproduksi selama suatu periode tertentu.Penelitian ini bertujuan untuk mengetahui perhitungan harga pokok produksi pada PT. Massindo Sinar Pratama.Analisis dilakukan dengan menggunakan metode deskriptif yang di kualitatifkan menjadi suatu metode dengan mengumpulkan data, disusun, diinterpretasikan, dan dianalisis sehingga memberikan gambaran mengenai keadaan subjek dan objek yang diteliti berdasarkan fakta yang ada. Dari hasil penelitian ini dapat diketahui dalam proses produksi springbed, pembebanan biaya produksi berdasarkan tipe dan ukurannya yang dihasilkan pada periode satu bulan. Dengan membebankan biaya bahan baku langsung, biaya tenaga kerja langsung, dan biaya overhead pabrik. Bahan baku langsung yang digunakan meliputi; Busa, Kain springbed, Spriral besi, Kayu,dan Kaki plastik. Pembebanan biaya tenaga kerja langsung berdasarkan tarif unit produksi yang dihasilkan.Pembebanan biaya overhead pabrik pada produk berdasarkan biaya overhead ditentukan dimuka.
\end{abstract}

Kata kunci : Harga pokok produksi

\begin{abstract}
Determination of the cost of production is an important problem in a manufacturing company where the activity is to process the raw materials into finished materials subsequently sold to consumers for a profit. Cost of production is the cost of production which has applied to all finished products are being manufactured during a certain period. This study aims to determine the calculation of the cost of production at PT. Massindo Sinar Pratama. Analyses were performed using the descriptive method in qualitative to be a method to collect data, compiled, interpreted, and analyzed so as to provide an overview of the state of the subject and the object under study is based on facts. From these results it can be seen in the production process of spring, charging based on the type and size of production resulting in a period of one month. With the charge of direct materials, direct labor costs and factory overhead costs. Direct materials used include; Foam, Cloth spring, Spriral iron, wood, and plastic legs. The imposition of direct labor costs based on rates of production units produced. Imposition of factory overhead costs to products based on the overhead costs are determined upfront.
\end{abstract}

Keyword : Cost of production 


\section{PENDAHULUAN}

\section{LatarBelakang}

Di tengah-tengah persaingan dunia bisnis sekarang ini maka manajemen perusaahaan perlu mempunyai perencanaan dan pengendalian yang matang agar dapat mencapai tujuan perusahaan itu sendiri dan dapat menentukan arah perusahaan jangka panjang. Hansen \& Mowen (2009:422), mengatakan perencanaan adalah pandangan ke depan untuk melihat tindakan apa yang seharusnya dilakukan agar dapat mewujudkan tujuantujuan tertentu. Pengendalian adalah melihat kebelakang, menentukan apakah yang sebenarnya telah terjadi, dan membandingkannya dengan hasil yang direncanakan sebelumnya. Kemudian perbandingan ini dapat digunakan untuk menyesuaikan anggaran yaitu melihat ke masa depan sekali lagi. Perencanaan dan pengendalian merupakan aktifitas yang berbeda, namun terkait sangat erat.Untuk memaksimalkan manfaat perencanaan (misalnya anggaran biaya), manajer harus menggunakan rencana tersebut untuk melakukan pengendalian.Sulit sekali melakukan pengendalian biaya tanpa sebuah rencana (Horngren, et al. 2008:9).

Dalam perencanaan tersebut manajemen selalu diperhadapkan pada pengambilan keputusan dari berbagai alternatif tindakan yang tersedia. Dalam proses pengambilan keputusan yang diambil haruslah merupakan keputusan yang paling menguntungkan bagi perusahaan. Salah satunya kebutuhan manajemen terhadap informasi keuangan yang berhubungan dengan penentuan harga pokok produksi.

Penentuan harga pokok produksi merupakan masalah penting dalam perusahaan manufaktur dimana kegiatannya adalah mengolah bahan mentah menjadi bahan jadi selanjutnya dijual ke konsumen untuk memperoleh laba.Harga pokok merupakan gambaran kwalitatif dari pengorbanan yang harus dilakukan pada penukaran barang atau jasa yang dilakukan di pasar. Produk yang mempunyai harga pokok produksi lebih tinggi dari produk lainnya yang sejenis di pasar akan menyebabkan kesulitan bagi manajemen perusahaan dalam mengantisipasi permainan harga yang dilakukan oleh pesaingnya. Tingginya harga pokok produksi dalam suatu produk biasanya disebabkan oleh beberapa hal, antara lain : yang pertama, kesalahan dalam menghitung harga pokok produksinya dan membengkaknya biaya produksi akibat terjadinya pemborosan pemakaian sumber daya perusahaan karena kurangnya pengawasan dalam proses produksi. Kedua, hal ini pada dasarnya sangat dipengaruhi oleh kurang tepatnya metode harga pokok produksi yang diterapkan oleh perusahaan.

Krismiaji \& Aryani (2011:325), penentuan harga jual adalah menambahkan angka perkiraan laba (Markup) pada angka harga pokok.Markup adalah selisih antara harga jual dengan harga pokok produk.Markup biasanya berupa presentase tertentu dari harga pokok produk. Kesalahan penentuan harga akan berakibat fatal. Jika harga ditentukan terlalu mahal, pelanggan akan enggan membeli produk perusahaan dan akan berpindah ke perusahaan lain. Jika harga jual ditentukan terlalu murah, maka biaya produksi yang dikeluarkan oleh perusahaan tidak akan tertutup sehingga perusahaan akan mengalami kerugian.

Dalam banyak hal, keberhasilan suatu usaha tergantung pada informasi harga pokok. Harga pokok produksi merupakan elemen penting dalam penentuan harga jual yang layak dan kompetitif untuk suatu produk. Walaupun harga pokok produksi bukan satu-satunya informasi yang digunakan untuk penetapan harga, akan tetapi jika harga suatu produk tidak dapat menutupi biaya produk, maka perusahaan tidak akan mendapatkan, menghasilkan atau memperoleh laba tetapi menderita rugi.

Perusahaan-perusahaan hanya mampu menghasilkan produk-produk yang mempunyai mutu yang lebih baik dengan harga yang rendah dengan berpedoman bahwa konsumen hanya dibebani dengan biaya-biaya untuk menambah nilai (value-added-activities), dengan demikian manajemen perusahaan memerlukan informasi biaya yang teliti, yang memperhitungkan secara cermat sumber data yang dikorbankan untuk aktivitas menambah nilai bagi konsumen. Informasi harga pokok sering dijadikan dasar untuk peramalan biaya dimasa yang akan datang.

Dengan dilengkapi beberapa metode penentuan harga pokok produksi seperti full costing, variabel costing, activity based costing memudahkan manajemen perusahaan menentukan tarif produksi. Selanjutnya dalam penelitian ini, penulis menggunakan metode full costing untuk membuat perhitungan harga pokok produksi.

PT. Massindo Sinar Pratama adalah perusahaan meubel yang berpartisipasi secara massa dimana proses produksinya dilakukan secara terus menerus (continue) untuk mengisi persediaan. Proses produksi yang dilakukan oleh PT. Massindo Sinar Pratama menghasilkan salah satu produknya adalah spring bed, dimana hasil dari produksi spring bed tersebut yang kemudian akan dijual kepada konsumen atau perusahaan lain.

Keberhasilan suatu usaha akan timbul apabila perusahaan membuat laporan biaya produksi yang lebih tepat, dengan memasukkan semua unsur biaya kedalam harga pokok produksi baik yang bersifat variabel maupun yang bersifat tetap. 


\section{TINJAUAN PUSTAKA}

\section{Akuntansi}

Akuntansi adalah suatu sistem untuk mengukur aktivitas bisnis, sebagai proses pencatatan yang menghasilkan laporan mengenai aktivitas ekonomi dan kondisi perusahaan serta mengkomunikasikan hasilnya kepada pihak-pihak berkepentingan sebagai cara untuk pengambilan keputusan bisnis.

\section{Tipe Akuntansi}

Akuntansi dalam suatu organisasi atau perusahaan dibagi menjadi dua tipe, yaitu akuntansi keuangan dan akuntasi manajemen.Akuntansi keuangan lebih difokuskan pada laporan secara menyeluruh tentang keuangan suatu organisasi yang dapat dipergunakan oleh pihak-pihak eksternal, sedangkan akuntansi manajemen menitikberatkan pada penyusunan laporan keuangan perbagian dalam suatu organisasi, yang dipergunakan oleh pihak intern seperti direktur, sehingga akuntansi manajemen disebut pula akuntansi intern.

\section{Tipe dan Manfaat Akuntansi Manajemen}

1. Tipe Informasi Akuntansi Manajemen

Mulyadi (2011:17), Berdasarkan hubungan dengan obkjek informasi, alternatif yang akan dipilih, dan wewenang manajer, informasi akuntansi manajemen dapat dibagi atas tiga tipe informasi akuntansi yaitu :

a. Jika akuntansi manajemen dihubungkan dengan objek informasi, seperti produk, departemen, atau aktivitas, maka akan dihasilkan konsep informasi akuntansi penuh.

b. Jika informasi akuntansi manajemen dihubungkan dengan alternatif yang akan dipilih, maka akan dihasilakan konsep informasi akuntansi diferensial, yang sangat diperlukan oleh manajemen dalam pengambilan keputusan pemilihan alternatif.

c. Jika informasi akuntansi manajemen dihubungkan dengan wewenang manajer, dihasilkan konsep informasi akuntansi pertanggungjawaban, yang terutama bermanfaat untuk mempengaruhi perilaku manusia dalam organisasi.

2. Manfaat Informasi Akuntansi Manajemen

Ketiga tipe informasi akuntansi manajemen tersebut dapat meliputi aktiva, pendapatan, dan biaya. Informasi akuntansi manajemen menyangkut informasi masa lalu dan informasi masa yang akan datang, tergantung untuk apa informasi tersebut disajikan.

Informasi akuntansi penuh yang berisi informasi masa yang lalu bermanfaat untuk pelaporan informasi keuangan kepada manajemen puncak dan pihak luar perusahaan, analisis kemampuan untuk menghasilkan laba, pemberian jawaban atas pertanyaan "berapa biaya yang dikeluarkan untuk sesuatu?" dan penentuan harga jual dalam cost type contract, informasi akuntansi penuh yang berisi informasi mana yang akan datang bermanfaat untuk penyusunan program, penentuan harga jual normal, penentuan harga transfer, dan penentuan harga jual yang diatur dengan peraturan pemerintah.

Informasi akuntansi diferensial mempunyai dua unsur pokok yaitu meurupakan informasi masa yang akan datang dan informasi yang berbeda diantara alternatif yang akan dipilih. Informasi ini diperlukan oleh manajemen untuk pengambilan keputusan mengenai pemilihan alternatif tindakan yang terbaik diantara alternatif yang tersedia. Karena pengambilan keputusan selalu menyangkut masa depan, maka informasi akuntansi yang relevan adalah informasi masa yang akan datang.

Informasi akuntansi pertanggung jawaban merupakan informasi aktiva, pendapatan dan/atau biaya yang dihubungkan dengan manajer yang bertanggung jawab atas pusat pertanggungjawaban tertentu. Informasi akuntansi pertanggungjawaban yang berisi informasi masa lalu bermanfaat untuk penilaian kinerja manajer dan pemotivasian manajer. Sedangkan informasi masa yang akan datang bermanfaat untuk penyusunan anggaran

\section{Akuntansi Manajemen}

Akuntansi manajemen adalah sebagai alat untuk penyediaan informasi yang diperlukan secara spesifik baik keuangan maupun non keuangan kepada pihak intern perusahaan yaitu pihak manajemen dalam pembuatan keputusan dan karyawan yang jarang disebarkan kepada pihak-pihak lain. 


\section{Akuntansi Biaya}

Mulyadi (2012:7), Akuntansi Biaya adalah proses pencatatan, penggolongan, peringkasan dan penyajian biaya, pembuatan dan penjualan produk atau jasa, dengan cara-cara tertentu, serta penafsiran terhadapnya. Akuntansi biaya yakni suatu proses untuk menganalisis biaya organisasi atau perusahaan dalam pembuatan dan penjualan produk atau jasa serta dapat membantu manajemen dalam pengawasan biaya. Akuntansi biaya ditekankan pada biaya produksi.

\section{TujuanAkuntansi Biaya}

Tujuan akuntansi biaya adalah menyediakan salah satu informasi yang diperlukan oleh manajemen dalam mengelola perusahaan, yaitu untuk :

1. Penentuan harga pokok produksi.

Untuk memenuhi tujuan penentuan harga pokok produk dilakukan pencatatan, penggolongan, dan peringkasan biaya-biaya yang pembuatan produk atau penyerahan jasa dengan cara-cara tertentu.

2. Pengendalian biaya.

Untuk memenuhi tujuan pengendalian biaya, maka biaya pembuatan produkyang seharusnya terjadi ditetapkan lebih dahulu.

3. Pengambilan Keputusan oleh Manajemen.

Untuk pengambilan keputusan, akuntansi biaya menyediakan informasi masa yana akan datang karena pengambilan keputusan berhubungan dengan masa depan.

\section{Biaya}

Mulyadi (2012:8), dalam arti luas biaya adalah pengorbanan sumber ekonomi, yang diukur dalam satuan uang, yang telah terjadi atau kemungkinan akan terjadi untuk tujuan tertentu. Jadi biaya bisa dikatakan sebagai nilai pengorbanan untuk mencapai tujuan tertentu yang diukur dalam satuan uang dan bisa memberi manfaat dimasa yang akan datang bagi organisasi atau perusahaan.

\section{Pengambilan Biaya Produksi}

Hansen \& Mowen (2009:56), mengatakan biaya produksi adalah biaya yang berkaitan dengan pembuatan barang dan penyediaan jasa. Biaya produksi terbagi atas tiga bagian yaitu:

1. Bahan baku langsung adalah bahan baku yang dapat ditetelusuri pada barang atau jasa yang dihasilkan. Misalnya baja pada mobil, kayu pada perabotan.

2. Tenaga kerja langsung adalah tenaga kerja yang dapat ditelusuri pada barang atau pelayanan yang dihasilkan.

3. Overhead pabrik meliputi semua biaya produksi langsung selau bahan baku langsung dan tenaga kerja langsung. Contohnya penyusutan bangunan, peralatan dan pemeliharaan.

Berkaitan dengan pengertian diatas penulis mengambil kesimpulan untuk pengambilan biaya produksi melalui biaya yang relative mudah untuk dikendalikan untuk menghasilkan sebuah produk jadi yang siap untuk dipasarkan.

\section{Harga Pokok Produksi}

Harga pokok produksi adalah biaya produksi yang diterapkan oleh seluruh produk jadi yang telah selesai diproduksi selama suatu periode tertentusedangkan biaya produksi yang melekat pada barang yang belum selesai tidak dapat dimasukkan sebagai harga produksi, dimana biaya produksi tersebut terdiri dari bahan baku, tenaga keja, dan overhead pabrik.

\section{Elemen Harga Pokok Produksi}

Elemen-elemen dalam harga pokok produksi adalah sebagai berikut:

a. Biaya Bahan Baku Langsung

Biaya bahan baku langsung adalah bahan baku yang dapat ditelusuri pada barang atau jasa yang dihasilkan. Biaya dari bahan-bahan dapat dikenakan pada produk karena pengamatan fisik dapat digunakan untuk mengukur jumlah yang dikonsumsi oleh tiap produk.

b. Biaya Tenaga Kerja Langsung

Muyadi (2012:319), biaya tenaga kerja adalah harga yang dibebankan untuk penggunaan tenaga kerja manusia tersebut. Tenaga kerja langsung adalah tenaga kerja yang dapat ditelusuri pada barang atau pelayanan 
yang dihasilkan. Karyawan yang mengubah bahan mentah menjadi produk atau yang menyediakan jasa pelayanan pada pelanggan diklasifikasikan sebagai tenaga kerja langsung.

c. Biaya Overhead Pabrik

Biaya overhead pabrik adalah semua biaya produksi selain dari bahan baku langsung atau tenaga kerja langsung dikumpulkan menjadi satu kategori. Dalam biaya overhead pabrik tidak termasuk biaya penjualan dan biaya administrasi dan umum, karena biaya penjualan dan biaya administrasi dan umum tidak timbul dalam proses produksi secara tidak langsung. Namun biaya jenis ini dapat pula dicatat dalam laporan biaya overhead pabrik.

\section{Tujuan Penentuan Harga Pokok Produksi}

Penentuan harga pokok produksi bertujuan untuk mengetahui seberapa besar biaya yang telah dikorbankan dalam hubungannya dengan pengolahan bahan baku menjadi barang jadi yang siap untuk dijual. Penentuan harga pokok sangat penting dalam suatu perusahaan, karena merupakan salah satu elemen dasar yang dapat digunakan sebagai sumber informasi bagi manajemen dalam mengambil keputusan yang tepat untuk kelangsungan proses produksi perusahaan.

\section{Penentuan Harga Pokok Produksi}

Harga pokok produksi merupakan dasar penentuan harga jual produk. Harga pokok adalah elemen penting dalam mempengaruhi laba. Untuk menentukan harga pokok produk, perlu adanya penggolongan biaya pada perusahaan manufaktur kedalam biaya produksi dan biaya non produksi. Ini disebabkan oleh karena biaya-biaya produksi saja yang melekat pada produk.

\section{Metode Penentuan Harga Pokok Produksi}

Ketidaktepatan dalam perhitungan Harga Pokok Produksi membawa dampak yang merugikan bagi perusahaan, karena Harga Pokok Produksi berfungsi sebagai dasar untuk menetapkan harga jual dan laba, sebagai alat untuk mengukur efisiensi pelaksanaan proses produksi serta sebagai dasar untuk pengambilan keputusan bagi manajemen perusahaan. Oleh karena itu, ada tiga konsep metode penentuan harga pokok produksi yaitu:

\section{Metode Activity Based Costing (ABC)}

Metode $A B C$ adalah sistern akurnolasi dan alokasi biaya yang rnenelusuri biaya-biaya ke produk rnenurut aktivitas-aktivitas yang dilakukan terhadap produk, dirnaksudkan untuk rnenghasilkan informasi biaya bagi keputusan strategis, perancangan, dan pengendalian operasional. Sehingga harga pokok yang dihitung dengan pendekatan rnetode $A B C$ klasifikasi biaya terdiri dari: biaya tingkat unit, biaya tingkat batch, biaya tingkat produk dan biaya tingkat fasilitas.

\section{MetodeFull Costing}

Merupakan metode penentuan harga pokok produksi yang memperhitungkan semua unsur biaya produksi kedalam harga pokok produksi. Harga pokok produksi yang dihitung dengan pendekatan full costing terdiri dari unsur harga pokok produksi (Biaya bahan baku, Biaya tenaga kerja langsung, biaya overhead pabrik variabel dan biaya overhead pabrik tetap) ditambah dengan biaya non produksi (biaya pemasaran, biaya administrasi dan umum).

\section{Metode Variable Costing}

Variabel Costing merupakan metode penentuan harga pokok produksi yang hanya memperhitungkan biaya produksi yang berperilaku variabel ke dalam harga pokok produksi, yang terdiri dari biaya bahan baku, biaya tenaga kerja langsung, dan biaya overhead pabrik yang berperilaku variabel.

\section{Penelitian Terdahulu}

\begin{tabular}{llllllll}
\hline No & $\begin{array}{c}\text { Nama } \\
\text { Peneliti/ } \\
\text { Tahun }\end{array}$ & Judul & Tujuan & $\begin{array}{c}\text { Metode } \\
\text { Penelitian }\end{array}$ & Hasil Penelitian & Persamaan & Perbedaan \\
\hline 1. & Irma & Analisis & Untuk & Deskriptif, & diketahui bahwa & Penelitian & Penelitian \\
& sari & harga pokok & mengetahui & dengan & dari perhitungan & sebelumnya & sebelumnya \\
& $(2012)$ & pesanan & dengan & menggunaka & harga pokok & menggunaka & ini lebih \\
& & meubel & menggunak & n data & pesanan & n metode & menekankan \\
& dengan & an metode & pesanan & berdasarkan teori & full & full costing \\
\hline
\end{tabular}




\begin{tabular}{llllll}
$\begin{array}{l}\text { metode full } \\
\text { costing pada }\end{array}$ & full costing & yang & dengan & costingterha & dalam harga \\
CV. Sarana & perhitungan & diterima & menggunakan & dap & pokok \\
interior di & harga & selama bulan & metode full costing & perhitungan & pesanan \\
Samarinda & pokok & maret 2012 & pesanan selama & $\begin{array}{l}\text { harga pokok } \\
\text { produksi }\end{array}$ & \\
& produk tiap & & bulan Maret 2012 & & \\
& pesanan & & masih dapat & \\
meubel & & menghasilkan laba & \\
& pada CV & atau keuntungan. & \\
& Sarana & & \\
Interior di & & & \\
& Samarinda & & \\
masih & & & \\
& menghasilk & & \\
& an laba atau & & \\
tidak. & & & \\
\hline
\end{tabular}

\section{METODE PENELITIAN}

\section{Jenis Penelitian}

Bentuk penelitian ini yang digunakan oleh penulis adalah metode deskriptif yaitu menjelaskan dengan sistematis, aktual, dan pemecahan masalah dengan menggambarkan keadaan subjek dan objek penelitian berdasarkan fakta yang ada.

\section{Metode Pengumpulan Data}

1. Observasi

Yaitu metode pengumpulan data yang diambil dengan melakukan pengamatan terhadap objek yang diteliti

2. Wawancara

Mengadakan wawancara secara langsung atau lisan dengan karyawan yang berwenang, terutama pada saat pengambilan data yang dibutuhkan.

3. Dokumentasi

Metode pengumpulan data dengan mencatat informasi yang didapatkan melalui proses wawancara pada pimpinan PT. Massindo Sinar Pratama.

4. Kepustakaan

Mengumpulkan beberapa konsep teori secara kepustakaan yang diperlukan untuk penelitian ini.

\section{Metode Analisis}

Analisis dilakukan dengan menggunakan metode deskriptif yang di kualitatifkan yaitu suatu metode dengan mengumpulkan data, disusun, diinterpretasikan, dan dianalisis sehingga memberikan keterangan bagi pemecahan masalah yang dihadapi.

\section{HASIL PENELITIAN DAN PEMBAHASAN}

\section{Sejarah Perusahaan}

PT. Massindo Sinar Pratama adalah salah satu perusahaan swasta yang ada di Manado, Sulawesi Utara yang bergerak di bidang manufaktur.Ada empat jenis produk yang dihasilkan yaitu Kasur Busa, Plastik Rabbit, Sofa dan Spring Bed.Perusahaan ini didirikan pada bulan Januari tahun 1984 oleh seorang pengusaha bernama William Massie dan pada awalnya perusahaan ini bernama CV. Abadi Jaya Bersama. Produk awalnya pada waktu itu adalah Busa dan Sofa kemudian berkembang dengan didirikannya pabrik Plastik Intection pada tahun 1989 yang memproduksi barang-barang plastik dengan Rabbit Star yang digunakan untuk keperluan rumah tangga dan diresmikan oleh Presiden Republik Indonesia Bapak Soeharto yang diwakili oleh Menteri Perindustrian Republik Indonesia Bapak Hartanto pada tahun 1993.

Dengan adanya upaya-upaya yang dilakukan oleh perusahaan dalam rangka mengembangkan serta meningkatkan produktifvtas ini maka pada tahun 1995 perusahaan ini dinilai layak oleh pemerintah untuk 
menerima penghargaan di bidang produktivitas berupa trophy "Sidakarya". Di dalam menghadapi persaingan di pasar internasional maka pada tanggal 10 Desember 1998 di kantor Notaris Thressje Sembung, SH perusahaan berganti nama menjadi PT. Massindo Sinar Pratama dan perusahaan ini dipegang oleh Massindo Group yang memiliki kantor pusat di Jakarta, hal ini disebabkan ibukota Negara Republik Indonesia.

Perusahaan ini bekerja sama dengan top USA seprai perusahaan dalam membawa kasur terbaik merek dan inovasi produk untuk keluarga Indonesia dan berbagai jaringan hotel internasional. Perusahaan memenangkan "Rekor Bisnis Indonesia" (Indonesia Rekor Bisnis) sebagai "pertama tidur perusahaan dengan jumlah terbesar dealer aktif " pada tahun 2011 dari Yayasan Tera dan surat kabar nasional Seputar Indonesia. Massindo Group juga menerima Penghargaan Pemasaran untuk Inovasi Produk dan Pemasaran Experiental tahun 2012 oleh Majalah Marketing. Salah satu merek, nyaman, menerima "The Most Preferred Brand" dalam Bedding berdasarkan survei konsumen independen pada tahun 2011 dan kemudian sekali lagi pada tahun 2012. Massindo Group memiliki kasur kelas dunia pabrik di berbagai kota di Indonesia .Pabrik terbesar di Bekasi disertifikasi oleh ISO 9001 oleh SGS United Kingdom Ltd Sistem dan Jasa Sertifikasi.

\section{Letak dan Lokasi Perusahaan}

PT. Massindo Sinar Pratama terletak di penghujung kota manado, yaitu di jalan cereme kelurahan Tuminting kota Manado, Provinsi Sulawesi Utara. Website: www.massindo.com

Lokasi dari PT. Massindo Sinar Pratama itu sendiri, sangat baik untuk sebuah perusahaan manufaktur karena memiliki area yang besar dan memiliki jarak yang cukup jauh dari pusat kota sehingga tidak mengganggu aktifitas warga masyarakat perkotaan dan perusahaan lebih leluasa untuk melakukan aktivitasnya untuk memproduksi barang dan memasarkannya.

\section{Proses Produksi}

Proses produksi pembuatan produk spring bed dibagi ke dalam tiga bagian yaitu:

a. Proses Produksi Rangka

Bahan dasar untuk memproduksi rangka produk spring bed ini adalah Kayu Merah. Kayu Merah itu sendiri berasal dari daerah Kotamobagu yang diambil oleh cabang perusahaan Massindo grup Kotamobagu kemudian di kirimkan ke Manado yang digunakan untuk proses pembuatan rangka. Proses pembuatan rangka dimulai dengan pemotongan kayu merah sesuai dengan model yang ingin dihasilkan. Dengan membuat difan atau sandaran tempat tidur dengan kayu merah yang telah dihaluskan dan dipotong membentuk sandaran tempat tidur. Pegangan-pegangan yang telah di potong rapi lalu disambungkan dengan difan hingga membentuk potongan suatu rangka tempat tidur dengan bantuan lem, kawat dan paku di setiap sambungan yang ada.

b. Proses penjahitan

Bagian ini bertugas untuk menghasilkan kasur-kasur yang akan dipasangkan pada rangka spring bed. Pada bagian penjahitan ini, terlebih dahulu busa yang ada akan dipotong-potong sesuai dengan ukurannya menggunakan alat pemotong busa. Kemudian didalam busa akan dipasangkan Pocketed Spring atau pegas yang terbungkus secara independen satu persatu yang berfungsi untuk memberikan support yang lebih kuat, lebih tahan lama dan lebih anti goncangan dari pasangan tidur dan juga mereka menambahkan side support rangkaian kawat baja untuk memperkuat setiap sisi kasur agar lebih tahan lama dan kuat menahan berat badan manusia. Setelah itu, akan dijahit dengan kain sesuai kebutuhan dan model atau motif yang diinginkan menggunakan mesin jahit sehingga menjadi sebuah kasur yang siap untuk dipakai.

c. Proses akhir

Yang dimaksud dengan proses akhir ini adalah merupakan tahap penyelesaian produksi dari rangka hingga menjadi spring bed yang siap untuk di pasarkan. Kasur yang telah jadi akan dipasangkan pada rangka spring bed, dan rangka tersebut akan dilapisi kain sesuai dengan model atau motifnya dengan menggunakan paku dan lem. Dan di bagian bawah rangka spring bed akan dipasangkan kaki spring yang terbuat dari plastik. Produk spring bed yang telah jadi dicatat oleh bagian administrasi produksi dan disimpan dalam gudang barang jadi dan disiap untuk dipasarkan.

\section{Hasil Penelitian dan Pembahasan}

Pada penelitian ini hanya difokuskan pada penentuan harga pokok produksi dari produk Spring Bed. Perusahaan ini memproduksi berbagai tipe spring bed dan berbagai ukuran yang meliputi: special anak, ukuran 100X200, ukuran 120X200, ukuran 160X200, ukuran 180X200, dan ukuran 200X200. Untuk memproduksi 
produk tersebut, perusahaan mengeluarkan biaya-biaya produksi meliputi: biaya bahan baku, biaya tenaga kerja, dan biaya overhead pabrik.

Untuk memproduksi produk ini memerlukan bahan baku utama yang meliputi bahan-bahan sebagai berikut:

1. Busa

2. Kain springbed

3. Spiral besi (pocketed spring)

4. Kayu merah dalam berbagai ukuran dan

5. Kaki plastik

Kebutuhan bahan baku bergantung pada berbagai ukuran yang ada. Hal ini karena tipe dari masingmasing springbed berbeda-beda. Ukuran 120 X200 misalnya, akan lebih sedikit jika dibandingkan dengan ukuran 200X200.

Dalam pembuatan produk tersebut di atas, perusahaan menggunakan tenaga kerja yang akan merakit springbed, difan, dan sandarannya. Pengeluaran biaya ini berdasarkan tarif yang telah ditentukan oleh perusahaan. Sehingga besarnya biaya tenaga kerja bersesuaian dengan besarnya ukuran springbed tersebut.

Dalam proses produksi produk-produk tersebut, perusahaan juga mengeluarkan biaya-biaya yang tidak dapat digolongkan sebagai biaya bahan baku dan biaya tenaga kerja langsung. Biaya-biaya yang dimaksudkan ini disebut biaya overhead pabrik. Adapun biaya-biaya tersebut meliputi : biaya penyusutan mesin dan peralatan, biaya penyusutan gedung pabrik, biaya gaji supervisor, biaya gaji petugas pabrik, biaya bbm solar, dan biaya bahan baku tidak langsung. Adapun biaya bahan baku tidak langsung meliputi: paku, lem, benang, kertas, dan plastik.

Dalam menganalisa harga pokok produksi, ada beberapa metode yang dapat digunakan yaitu biaya penuh, biaya variabel, dan biaya berdasarkan aktivitas. Pada pembahasan ini menggunakan biaya penuh. Pada metode biaya penuh, biaya produksi dari suatu produk meliputi biaya bahan baku langsung, biaya tenaga kerja langsung, dan biaya overhead pabrik (biaya tidak langsung pabrik).

\section{Pembebanan Biaya Bahan Baku}

Pembebanan biaya bahan baku langsung pada ukuran 100X200 untuk masing-masing bahan baku langsung adalah sebagai berikut : pemakain busa dibebankan dengan cara jumlah lembar busa yang di pakai dikalikan dengan harga perlembar (perusahaan menggunakan metode FIFO untuk arus biaya bahan); pemakaian kain springbed dibebankan dengan cara jumlah meter kain yang digunakan dikalikan dengan harga permeter kain; spiral besi dibebankan dengan cara jumlah spiral dikalikan dengan harga spiral besi perbuah; pemakaian kayu dibebankan dengan cara jumlah potong kayu (biasanya perujung) dikalikan dengan harga perpotong; sedangkan kaki plastik dibebankan dengan cara jumlah kaki plastik dikalikan dengan harga perbuah kaki plastik. Hal yang sama dilakukan pada tipe dan ukuran seperti yang disebutkan di atas. Jadi biaya bahan baku langsung yang dibebankan pada masing-masing produk besarnya akan bergantung pada ukuran dan jenis bahan yang di pakai.

Bila memperhatikan pembebanan biaya bahan baku langsung tersebut di atas maka perhitungan harga pokok produksi dari produk yang dihasilkan sudah menggolongkan biaya-biaya produk yang sesuai. Hal ini karena biaya bahan baku langsung dapat diidentifikasi jumlah volume yang digunakan. Atau dengan kata lain biaya bahan baku langsung dapat ditelusuri jumlah volume yang digunakan. Pemakaian Busa, Kain springbed, Spiral besi, Kayu, dan Kaki plastik pada produk berdasarkan ukuran-ukuran yang ada. Biaya bahan baku langsung yang dibebankan pada masing-masing produk berdasarkan tipe ukuran dari springbed tersebut.

\section{Pembebanan Biaya Tenaga Kerja}

Untuk biaya tenaga kerja, perusahaan membebanan biaya tenaga kerja langsung pada masing-masing produk adalah berdasarkan tarif unit produksi yang dihasilkan. Hal ini dilakukan karna perusahaan dapat mengidentifikasi pekerja-pekerja yang melakukan kegiatan produksi pada jenis atau tipe produk yang dihasilkan. Untuk satu jenis ukuran misalkan, perusahaan menempatkan satu kelompok kerja yang melakukan pekerjaan dari awal sampai selesai dengan masing-masing tugas yang ada. Ini dilakukan untuk memudahkan proses perhitungan biaya dan pembayarannya. Sehingga pembebanannya sesuai dengan tipe dan ukuran yang di produksi.

Bila dikaitkan dengan teori yang ada maka pembebanan biaya tenaga kerja langsung tersebut dapat dikatakan memadai. Artinya bahwa pembebanan biaya tenaga kerja berdasarkan tarif perunit untuk tipe dan ukuran yang di produksi dapat diandalkan. 


\section{Pembebanan Biaya Overhead Pabrik}

Unsur biaya produksi yang dibebankan perusahaan berikutnya adalah biaya overhead pabrik. Sebagaimana diuraikan di atas bahwa biaya-biaya overhead pabrik (biaya-biaya tidak langsung) adalah meliputi biaya penyusutan mesin dan peralatan, biaya penyusutan gedung pabrik, biaya gaji supervisor, biaya gaji petugas pabrik, biaya bbm solar, dan biaya bahan baku tidak langsung. Adapun biaya bahan baku tidak langsung meliputi: paku, lem, benang, kertas, dan plastik.

Perusahaan membebankan biaya overhead berdasarkan biaya yang ditentukan dimuka. Dengan cara menghitung semua biaya overhead dalam satu bulan (perusahaan menggunakan satu bulan sama dengan 25 hari). Untuk mendapatkan biaya overhead perhari di hitung dengan cara membagi total biaya overhead perbulan dengan jumlah hari dalam sebulan. Dalam pembuatan produk, perusahaan telah menetapkan jumlah produksi tiap hari.

\section{Pembebanan Selisih Biaya Overhead Pabrik}

Dalam situasi tertentu perusahaan memproduksi di bawah target tetapi kemudian akan di isi kembali dengan melakukan kerja lembur. Keadaaan ini akan mempengaruhi besarnya biaya produksi. Terutama biaya overhead yang semi variabel misalnya biaya bahan bakar dan biaya listrik.Kelebihan atau kekurangan pembebanan biaya overhead diperlakukan sebagai pengurangan dan penambahan pada harga pokok produk yang diselesaikan pada periode tersebut.Situasi ini bila dikaitkan dengan teori maka dapat dikatakan memadai karena pembebanan dilakukan pada produk yang dihasilkan untuk periode tersebut. Ini juga memungkinkan manajer produksi menganalisa apa penyebabnya.

\section{PENUTUP}

\section{Kesimpulan}

Berdasarkan hasil penelitian dan pembahasan di atas maka dapat dikemukakan simpulan sebagai berikut:

1. Dalam tiga metode penentuan harga pokok produksi yaitu full costing, variabel costing, activity based costing. Metode full costing adalah metode penentuan harga pokok produksi yang tepat bagi PT. Massindo Sinar Pratama.

2. Dalam proses produksi springbed, pembebanan biaya produksi berdasarkan tipe dan ukuran yang dihasilkan pada periode satu bulan. Dengan membebankan biaya bahan baku langsung, biaya tenaga kerja langsung, dan biaya overhead pabrik.

3. Pembebanan biaya bahan baku langsung yaitu menjumlahkan semua komponen bahan dengan harga persatuan dari bahan tersebut. Bahan baku langsung yang digunakan meliputi; Busa, Kain springbed, Spriral besi, Kayu,dan Kaki plastik.

4. Pembebanan biaya tenaga kerja langsung berdasarkan tarif unit produksi yang dihasilkan.

5. Pembebanan biaya overhead pabrik pada produk berdasarkan biaya overhead ditentukan dimuka.

6. Pembebanan selisih biaya overhead dilakukan pada periode dimana terjadi selisih tersebut.

\section{Saran}

Dengan memperhatikan proses produksi dan pembebanan biaya produk pada produk yang dihasilkan maka hal yang perlu mendapat perhatian utama adalah pembebanan biaya overhead pabrik. Perusahaan dapat menganalisa berapa pemakaian listrik dan bahan bakar minyak perjam. Karena kapasitas terpasang sudah di ketahui.

\section{DAFTAR PUSTAKA}

Arfan Ikhsan, 2009. Pengantar Praktis Akuntansi.Edisi pertama.Cetakan pertama. Graha Ilmu. Yogyakarta.

Carles T. Horngren, Srikant M. Datar, George Foster, 2008. Akuntansi Biaya, Penekanan Manajerial. Jilid 1.Erlangga. Jakarta.

Don R. Hansen, Maryanne M. Mowen, 2009. Akuntansi Manajerial. Edisi 8. Salemba Empat. Jakarta. 
Eka Nur Khasanah, 2011. Penerapan Metode Full Costing Dalam Menentukan Harga Jual Batu Bara Pada PT. Energy Alam Sejahtera Di Samarinda. Jurnal Fakultas Ekonomi, Universitas Mulawarman.

Firdaus A. Dunia, Wasilah Abdulah, 2009. Akuntansi Biaya. Salemba Empat. Jakarta.

Horngren, Harrison, 2007. Akuntansi. Edisi Ketujuh. Jilid 1.Erlangga. Jakarta.

Irma Sari, 2012. Analisis Harga Pokok Pesanan Meubel Dengan Metode Full Costing pada CV. Sarana Interior di Samarinda. Jurnal Fakultas Ekonomi, Universitas Mulawarman.

Krismiaji, Y Anny Aryani, 2011. Akuntansi Manajemen. Edisi kedua. UPP STIM YKPN. Yogyakarta.

Kadir, Abdul, 2011. Panduan Menyusun Laporan Tugas Akhir, Skripsi, dan Tesis Menggunakan Microsoft Word. Mediakom.Yogyakarta.

Mulyadi, 2012.Akuntansi Biaya. Edisi kelima.Cetakan sebelas. UPP STIM YKPN. Yogyakarta.

P. Siagian masih(dalam Nanang Fatah (2007)). Manajemen Keuangan. Jilid 1.Gramediana. Bandung.

Sugiono, 2009.Memahami Penelitian Kualitatif. Alfabeta. Bandung.

Warren, Reevefess, 2008. Pengantar Akuntansi. Salemba empat. Jakarta.

Website: www.massindo.com 